\title{
Conceptual Framework for Evaluation of Diploma Program in Automotive Technology in Vocational Colleges in Malaysia
}

Muammar Shah Mukhter, Jamal @ Nordin Yunus, Fanny Kho Chee Yuet

To Link this Article: http://dx.doi.org/10.6007/IJARBSS/v12-i1/12245

DOI:10.6007/IJARBSS/v12-i1/12245

Received: 09 November 2021, Revised: 11 December 2021, Accepted: 29 December 2021

Published Online: 19 January 2022

In-Text Citation: (Mukhter et al., 2022)

To Cite this Article: Mukhter, M. S., Yunus, J. @ N., \& Yuet, F. K. C. (2022). Conceptual Framework for Evaluation of Diploma Program in Automotive Technology in Vocational Colleges in Malaysia. International Journal of Academic Research in Business and Social Sciences, 12(1), 1904-1910.

Copyright: (c) 2022 The Author(s)

Published by Human Resource Management Academic Research Society (www.hrmars.com)

This article is published under the Creative Commons Attribution (CC BY 4.0) license. Anyone may reproduce, distribute, translate and create derivative works of this article (for both commercial and non0-commercial purposes), subject to full attribution to the original publication and authors. The full terms of this license may be seen at: http://creativecommons.org/licences/by/4.0/legalcode

Vol. 12, No. 1, 2022, Pg. 1904- 1910

Full Terms \& Conditions of access and use can be found at http://hrmars.com/index.php/pages/detail/publication-ethics 


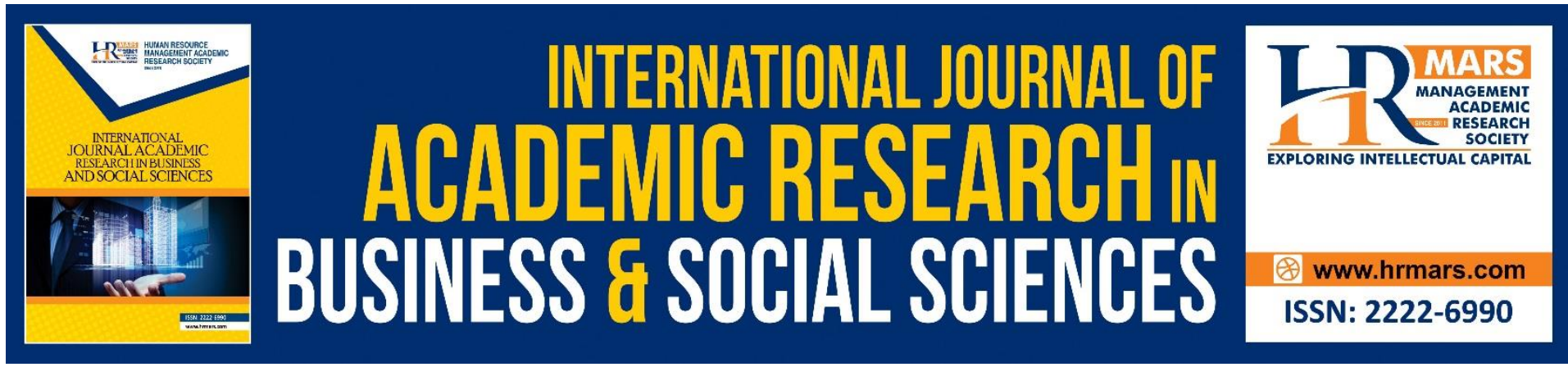

\title{
Conceptual Framework for Evaluation of Diploma Program in Automotive Technology in Vocational Colleges in Malaysia
}

\author{
Muammar Shah Mukhter, Jamal @ Nordin Yunus, Fanny Kho \\ Chee Yuet \\ Universiti Pendidikan Sultan Idris, Perak, Malaysia The Faculty of Management and \\ Economics \\ Email: amarshah2807@gmail.com
}

\begin{abstract}
This study was conducted to build a conceptual framework for evaluating diploma programs in automotive technology in vocational colleges in Malaysia. The researcher used a conceptual framework based on the study's theoretical framework, which focused on the context, input, process, and product (CIPP) evaluation model of Stufflebeam (1971). The findings indicate that this conceptual framework is suitable for use in this study at the next stage and can be adapted by other researchers.
\end{abstract}

\section{Introduction}

The transformation of vocational education is one of the main components of the Ministry of Education's success. Therefore, to mainstream vocational education, the curriculum has been revamped and strengthened to achieve standards that meet the needs of the job and current market. A transformation in vocational education has been created to achieve that goal (Rakyat, 2011). The branding of vocational secondary schools to Vocational Colleges (VC) began in 2012 with the implementation of the Vocational Education Transformation. VC is a post-secondary vocational education and training institution that implements the Vocational College Standard Curriculum (VCSC) to form a strong, knowledgeable, and highly skilled human capital. Vocational High School (VHS), which only produced Malaysian Certificate of Education (MCE) graduates at one time, is now given recognition to produce graduates with the Malaysian Vocational Diploma (DVM). The name SMV has been changed to Vocational College since 2012. Impact VC is a university-level higher education institution, and its first graduates graduated in 2015. CV was developed in the context of the general goal of the national education system to form a strong, knowledgeable, and highly skilled human capital in the field of technical and vocational education and training (TVET). In parallel with efforts undertaken by the Ministry of Education Malaysia (MOE) in tandem with the rapidly changing knowledge and information sector to improve the quality of education in Malaysia (Abu Hassan et al., 2021). 


\section{Research Objective}

- This study aims to build a conceptual framework for the evaluation of diploma programs in automotive technology in vocational colleges in Malaysia.

\section{Significance of the Study}

The need for a workforce today that leads to vocational skills in certain fields such as automotive, construction, engineering, apparel, and others is emphasized in selecting and placing positions appropriate to the industry involved. The shift in Malaysia's economic activities based on the production and export of key commodities to manufacturing, high technology, and knowledge-based industries has led to changes in the demand and needs of human resources, which has become a critical issue. This study is important to ensure that the evaluation methods are accurate and produce accurate and high-impact research results. It because if the assessment method is not appropriate, it will cause the findings of the study to be error and ultimately not be able to assess the weaknesses or strengths of the diploma program in automotive technology in vocational colleges in Malaysia.

\section{Conceptual Framework}

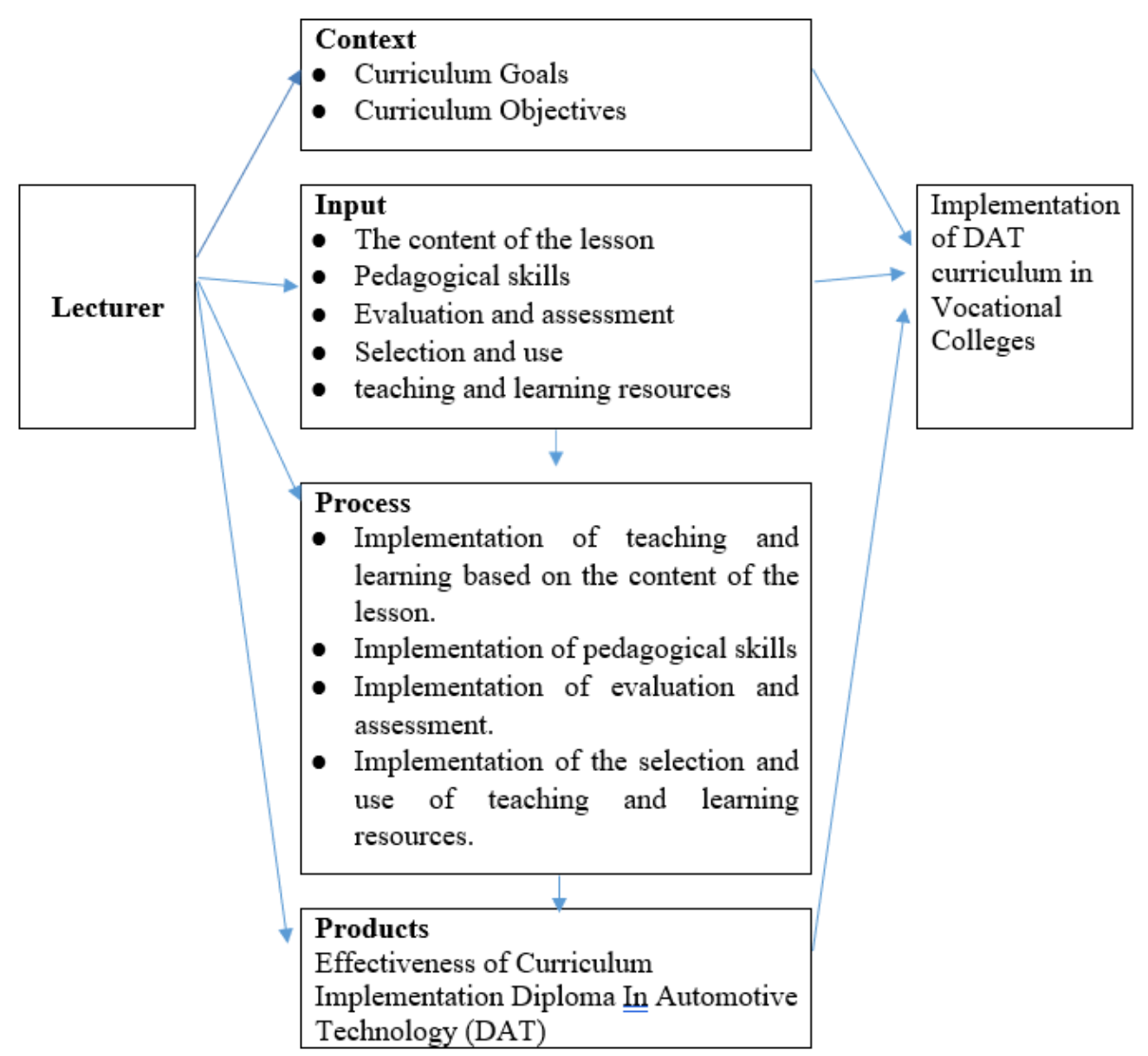

The researcher used a conceptual framework based on the Theoretical Framework of the Study, which focused on the Context, Input, Process and Product (CIPP) Evaluation model of (Stufflebeam, 1971). This conceptual framework focuses on the level of implementation of automotive lecturers in implementing the Diploma In Automotive Technology (DAT) curriculum of vocational colleges in Malaysia. The conceptual framework of this study 
explains the assessment of the level of implementation is made in four stages. The first stage starts from the context dimension, which evaluates the level of implementation of Automotive lecturers implementing the DAT curriculum based on the goals and objectives of the curriculum. In this dimension, the researcher wants to measure the level of implementation of Automotive lecturers implementing the DAT curriculum based on the requirements of FPK as well as the targets set for DAT courses. Context assessment describes the relevant environment, explains the actual program situation and identifies unmet needs, diagnoses barriers that prevent achieving needs, and obtains information about decision situations that meet program goals and objectives. According to Mintzes et al (2000), in conducting the teaching process, educators play a demanding role that can meet the needs of the curriculum. Curriculum changes that take place continuously from time to time require educators to adapt and ensure the country's life potential is excellent. Some training curricula shift practices from reactive to constructive, unproductive to productive, and passive to aggressive (Puteh \& Meerah, 2007).

In the second stage, input evaluation aims to identify how available resources are used to achieve objectives and identify program strategies to achieve the desired results. Che Amat \& Abdul Hakeem (2013) emphasize that input evaluation helps organize decisions by determining the resources available, alternative options that can be used, strategies, and work procedures to achieve the set objectives. Input of evaluation also involves the examination of potentially relevant approaches to alternative options. It serves as a structuring decision because alternative structural strategies meet the needs of a particular objective. Examples of input assessment components include teaching skills and knowledge, equipment, workshop facilities, timetable, funding allocation, or the role of the headteacher. This dimension focuses on the knowledge and mastery of lesson content, the use of teaching and learning strategies and methods, as well as the skills of lecturers in selecting teaching and learning resources. Educators who master the lesson's content can adapt the content to the students' abilities. This ability will indirectly help students better understand the topics discussed and influence students' academic achievement while ensuring that curriculum goals can be achieved (Darling, 2000).

In the third stage, process evaluation is used to evaluate the implementation of skills training programs. This dimension is used to see the implementation process of teaching and learning based on lesson content, teaching and learning strategies and methods, use of resources and reference materials, and the form of the assessment conducted on students. Next, the product evaluation is used to compare the actual results with the standards that have been accepted whether to continue, discontinue, modify or refocus activities and gather information regarding the program conducted. In terms of products, the researcher would like to see the level of implementation of Automotive lecturers to evaluate the effectiveness of the teaching and learning process carried out from the aspect of output. From here, the decision is made whether to make improvements to the strengths and skills that need to be mastered by science lecturers and identify suggestions to improve the effectiveness of the implementation of the DAT curriculum.

\section{Literature Review}

Curriculum assessment is one of the processes in curriculum development. Curriculum evaluation is not only necessary once the program has been implemented, but the evaluation is also conducted throughout curriculum development and curriculum implementation. Curriculum assessment is divided into two, namely formative assessment and summative 
assessment. Formative assessment is conducted during the curriculum development process. It is implemented on sub-units during the curriculum development process and tested in smaller situations to see its effectiveness. At the same time, Summative Evaluation aims to evaluate the overall quality of the program produced and implemented (Ornstein \& Hunkins, 2009).

Evaluation has various interpretations. In the aspect of the curriculum, assessment means gathering information about students, evaluating teacher performance, and gathering interaction information in the classroom. The evaluation also means identifying the strengths and weaknesses of activity in a program. Evaluation is a way of obtaining information and using it in decision making, gathering information to enable a decision to be made and the process of determining a decision on a particular matter, selecting appropriate information, and collecting and analyzing such information for decision-making purposes (Stufflebeam, 2003)

A model is a conceptual representation explaining the relationship between an activity and other related elements. Various models can be used as a guide in evaluating a curriculum or program. The CIPP Evaluation Model was developed by (Stufflebeam, 2003). The main concept of this model is taken from the acronym CIPP, namely context evaluation, input evaluation, process evaluation, and product evaluation. According to Stufflebeam (2003), the CIPP model is a comprehensive framework for implementing the formative or summative assessment. Many researchers and evaluators have used the CIPP model to evaluate the effectiveness of programs and curricula in institutions of higher learning at home and abroad because this model is designed for improvement and decision-making related to a course, program, or curriculum (Stuffllebeam \& Shinkfield, 1985).

The CIPP model is an evaluation model that aims to evaluate a program to improve the program, especially the programs offered in education and human services (Aziz et al., 2018). Stufflebeam (2008) acknowledges that CIPP is an evaluation model that can be a tool (tools) to help make a program better for the intended human benefit. According to Stufflebeam (1967), "the CIPP approach is the view-based, the main purpose of the assessment is not to prove but to improve." Based on the above quotation, the main purpose of CIPP is not to prove but to improve. The approach of this model is based on two main assumptions about evaluation. The first assumption is that evaluation plays an important role in stimulating and planning change. While the second assumption is that assessment is a complementary component to common institutional programs (James, 1993).

\section{Diploma in Automotive Technology Curriculum in Vocational Colleges}

The goal of the Diploma in Automotive Technology (DAT) program is to form Automotive Technologist Assistants who are willing to participate in the job market, competitive entrepreneurs, and able to further their studies to a higher level. The study period is five semesters, which is two years and six months. In addition, the Program Structure contains General Studies Courses, Core Courses, and Elective Courses. General Studies Courses consist of Compulsory Vocational College Courses and are compulsory for all students studying at VC. Credit hours are 10 credit hours. Core Courses consist of Vocational Majors. The Major Vocational courses offered are content knowledge and practical skills. The credit hours offered are 76 credit hours. Elective courses consist of two language courses, will choose either an Arabic or Mandarin course and credit hours are 4 credit hours. This subject is offered to students to improve their proficiency in Arabic or Mandarin. 
Table 1: Diploma Program Structure in Automotive Technology

\begin{tabular}{lll}
\hline No. & Course & Credit Hours \\
\hline 1 & General Studies Course & $10(12 \%)$ \\
2 & Core Courses & $76(84 \%)$ \\
3 & Elective Courses & $4(4 \%)$ \\
\hline & Total & $\mathbf{9 0 ( 1 0 0 \% )}$ \\
\hline
\end{tabular}

\section{Conclusion}

The evaluation model is very important to parse as the core of this study. There are a variety of models or approaches that can be used to evaluate a training program. Model is likened to a road that drives a person not to get lost. The model is a conceptual picture of an activity that can show the relationship between the various elements involved in the activity. Therefore, the conceptual framework constructed is in line with the model proposed by Stufflebeam, namely the CIPP Evaluation Model. Therefore, this study will be continued to the next stage to obtain data from vocational college graduates to ensure that the Diploma in Automotive Technology program has a curriculum that can meet the country's needs in the automotive area. The results of this study are expected to provide new added value in education and skills training. The findings obtained can be a guideline to various parties, especially the Ministry of Education Malaysia and the Vocational Training and Technical Education Division, in planning programs to improve the effectiveness of skills training centres, especially in vocational colleges. Skills training programs are a branch in the development of existing education and should be given attention and emphasis by training and mind development policymakers. From a policy perspective, the results obtained can provide the latest data that can be used to use aspects related to vocational skills training, especially the role of instructors and external parties in helping skills training more effectively. Policy-making divisions can use the results of this research at the Ministry of Education Malaysia and the Vocational Training and Technical Education Division levels to understand critical and current issues related to skills training centres in vocational colleges. Through the findings of this study, the conceptual framework constructed can help researchers conduct research accurately and effectively. It also can help future researchers to conduct research.

\section{References}

Abu Hassan, M. A., Gengatharan, K., Ramli, R., \& Mukhter, M. S. (2021). Issues of Teacher Professionalism in The Era of the COVID-19. International Journal of Academic Research in Business and Social Sciences, 11(8), 1117-1123.

Aziz, S., Mahmood, M., \& Rehman, Z. (2018) Implementation of CIPP Model for Quality Evaluation at School Level: A Case Study. Journal of Education and Educational Development, 5(1), 189-206

Che Amat, M. F., \& Abdul Hakeem, A. J. (2013). Menilai Keberkesanan Pelaksanaan Program Diploma Perguruan Lepas ljazah Pendidikan Sejarah Sekolah Rendah di Institut Pendidikan Guru Kampus Pulau Pinang. Seminar Pendidikan Sejarah Dan Geografi 2013, 215-225.

Darling, H. L. (2000). Teacher quality and student achievment: a review of state policy evidence . Journal of Education, 8 (1), 50-101.

Mintzes, J., Wandersee, J., and Novak, J. (2000). Assessing Science Understanding: A Human Constructivist View, San Diego: Academic Press 
Puteh, N. S., \& Meerah, M. S. (2007.). Cabaran dan Isu dalam Perancangan dan Pembangunan Kurikulum Persekolahan di Malaysia. Kuala Lumpur: Universiti Kebangsaan Malaysia.

Ornstein, A., \& Hunkins, F. (2009) Curriculum Design. In Curriculum: Foundations, Principles and Issues (5th Ed.), pp. 181-206. Boston, MA: Pearson/Allyn and Bacon.

Sharifah \& Subahan. (2007). Cabaran dan Isu dalam Perancangan dan Pembangunan Kurikulum Persekolahan di Malaysia.

Stufflebeam, D. L., \& Shinkfield, A. J. (1985). Systematic evaluation: a self-instruction guide to theory and practice. Boston: Kluwer-Nijhoff Publishing.

Stufflebeam, D. L. (1971). The relevance of the CIPP evaluation model for educational accountability. Journal of Research and Development in Education, 5(1), 19-25.

Stufflebeam, D. L. (2003). The CIPP model for program evaluation. Boston: Kluwer-Nijhoff Publishing. 